\title{
Agronomic characteristics, isoflavone content and Kunitz trypsin inhibitor of vegetable soybean genotypes
}

\author{
Renata Castoldi'; Hamilton César de O Charlo; Pablo F Vargas²; Leila T Braz; Mercedes C Carrão- \\ Panizzi $^{3}$ \\ ${ }^{1}$ UNESP-FCAV, Depto. Prod. Vegetal, Rod. Prof. Paulo Donato Castellane, s/n, 14884-900 Jaboticabal-SP, rcastoldi@gmail.com; \\ ${ }^{2}$ UEMG, Av. Juca Stockler, 1130, 37900-106 Passos-MG; 3Embrapa Soja, C. Postal 231, 86001-970 Londrina-PR
}

\begin{abstract}
Five vegetable soybean genotypes were evaluated for agronomic characteristics, functional and antinutritional properties. The experiments were conducted in the field, in the School of Agricultural and Veterinary Sciences, in Jaboticabal, São Paulo State, Brazil. The experimental design was a randomized block design with five treatments (genotypes) and four replications. The genotypes JLM003, JLM004, JLM010, JLM024 and JLM030 were evaluated in the following characteristics: number of pods per plant, number of seeds per pod, fresh weight of pods per plant $(\mathrm{g})$, fresh weight of 100 seeds $(\mathrm{g})$, estimated total yield of immature seeds $\left(\mathrm{kg} \mathrm{ha}^{-1}\right)$, moisture content, proteins, lipids, ash, carbohydrates, isoflavones and Kunitz trypsin inhibitor. In the assessment of the major agronomic traits, in the conditions of this study, the genotype JLM010 was the most recommended for the region of Jaboticabal. This genotype showed better agronomic characteristics of production as a vegetable, producing $136.04 \mathrm{~g}$ of fresh weight of pods per plant, $92.52 \mathrm{~g}$ of fresh weight/100 seeds and $11.12 \mathrm{t} / \mathrm{ha}$ of total immature seeds, and better functional properties.
\end{abstract}

Keywords: Glycine max, functional characteristics, antinutritional characteristics, proximate composition.

\section{RESUMO}

Características agronômicas, teor de isoflavonas e inibidor de tripsina Kunitz em genótipos de soja-hortaliça

Cinco genótipos de soja-hortaliça foram avaliados quanto às características agronômicas, propriedades funcionais e antinutricionais. O experimento foi conduzido em campo, no Setor de Olericultura e Plantas Aromático-Medicinais na UNESP-FCAV. O delineamento experimental foi de blocos ao acaso com cinco tratamentos (genótipos) e quatro repetições. Avaliaram-se os genótipos JLM003, JLM004, JLM010, JLM024 e JLM030 quanto às características de número de vagens por planta; número de sementes por vagem; massa fresca das vagens por planta (g); massa fresca de 100 sementes (g); produtividade total estimada de grãos imaturos $\left(\mathrm{kg} \mathrm{ha}^{-1}\right)$; teor de umidade; proteínas; lipídeos; cinzas; carboidratos; isoflavonas e inibidores de tripsina Kunitz (KSTI). Nas condições deste experimento, foi observado que o genótipo de soja-hortaliça JLM010 é o mais recomendado para a região de Jaboticabal, por apresentar melhores características agronômicas para produção como hortaliça o que inclui $136,04 \mathrm{~g}$ para massa fresca das vagens por planta, $92,52 \mathrm{~g}$ para massa fresca de 100 sementes e 11,21 t/ha para produtividade total estimada de grãos imaturos, e melhores propriedades funcionais.

Palavras-chave: Glycine max, características funcionais, características antinutricionais, composição centesimal.

\section{(Recebido para publicação em 31 de maio de 2010; aceito em15 de março de 2011)}

(Received on May 31, 2010; accepted on March 15, 2011)

$\mathrm{C}$ urrently, soybean (Glycine max) is one of the most important agricultural products in the Brazilian economy, highlighting the country's export tariff. Only about $2 \%$ of the national production is for direct consumption, while $70 \%$ of the production is exported as in natura grains (Brasil, 2007).

In the last years, the market has required quantity ally the quality, as, in response to the demand for products with greater aggregated value. On this basis, soybean cultivars have been developed with special characteristics for different uses such as green soybean, vegetable soybean or edamame (which is a traditional Japanese dish, immature pods cooked in salty water) (Embrapa, 2003).

For this type of products, some characteristics could be considered as large seeds, high protein content; yellow color hilum; absence of lipoxygenases (better flavor), and reduced level of Kunitz trypsin inhibitor, which allows reduced heat treatment (Embrapa, 2003).

Production system for vegetable soybeans differs from common soybeans only in the stage of harvest and postharvest procedures. The ideal harvest period is between 35 and 40 days after flowering, when the levels of saccharose are elevated, conferring sweeter taste to the seeds (Chiba, 1991).

The vegetable soybean or edamame can have good acceptability and constitute a healthy habit, as it is rich in protein $(13 \%)$, contains low oil content (5.7\%), non cholesterol and hydrogenated fat. It also presents reasonable levels of phosphorus, calcium and vitamins $\mathrm{B}_{1}$ and $\mathrm{B}_{2}$ (Shanmugasundaram \& Yan, 2004). 
Considering all these advantages, studies are needed to characterize the vegetable soybean cultivars. Therefore, evaluations of the agronomic performance, chemical composition, functional properties, and presence of antinutritional factors should be conducted. The present work evaluated performance of five vegetable soybean genotypes.

\section{MATERIAL AND METHODS}

The experiments were conducted in the field, from November 1, 2006 to March 19, 2007, in the experimental area of the Universidade Estadual de São Paulo, in Jaboticabal, São Paulo State (21 ${ }^{\circ} 14^{\prime} 05^{\prime} \mathrm{S}, 48^{\circ} 17^{\prime} 09^{\prime} \mathrm{W}$, altitude of $614 \mathrm{~m}$ ). The climate, according to the Köppen classification, is of the Aw type with transition to Cwa (Volpe ${ }^{1}$ ), and the soil of the experimental area was classified as being eutroferric latossolo (Embrapa, 1999).

The experimental design was randomized blocks with five treatments (genotypes) and four replicates. The utilized genotypes were previously tested in earlier studies and, that one presenting the best characteristics for consumption as vegetable, was used in the current experiment: JLM003 originated from the germplasm collection of Embrapa Hortaliças (medium size, dry weight of 100 seeds $=30 \mathrm{~g}$, purple flower, yellow hilum, yellow grain); JLM004 from Embrapa Hortaliças (medium size, dry weight of 100 seeds $=37 \mathrm{~g}$, purple flower; light brown hilum); JLM010 originated from Asian Vegetable Research and Development Center, Taiwan (medium size, dry weight of 100 seeds $=41 \mathrm{~g}$, white- flower; yellow hilum and seed), and JLM024 from germplasm collection of Embrapa Cenargen (tall size, dry weight of 100 seed $=19 \mathrm{~g}$,) and JLM030 from Embrapa Soja (medium size, dry weight of 100 seeds $=27.8 \mathrm{~g}$, yellow hilum).

Each experimental plot consisted of four rows 6 meters length, $0.60 \mathrm{~m}$ between rows and $0.15 \mathrm{~m}$ between plants. In each plot, 20 plants from two central rows were evaluated for all characteristics.
Due to intensive attacks of pigeons in previous direct seeding plantings, we decided to grow seedlings in Polystyrene trays with 128 cells, utilizing the commercial substrate Plantmax Hortaliças $^{\circledR}$ HT, where one seed was planted per cell. Seeds were previously inoculated with Bradyrhizobium spp, in the proportion of $500 \mathrm{~g}$ of innoculum per $50 \mathrm{~kg}$ of vegetable soybean.

The seedlings were transplanted 20 days after planting date, on November 21, 2006, when plants presented 2 or 3 definitive leaves and $12 \mathrm{~cm}$ height. At that time, they were removed from the trays and planted in the definitive location that was prepared according to conventional system of plowing and harrowing. Soil was fertilized five days before transplanting, based on soil analysis and recommendations of Raij et al. (1997). Fertilization consisted of $50 \mathrm{~kg} \mathrm{ha}^{-1}$ of $\mathrm{N}, 40 \mathrm{~kg} \mathrm{ha}^{-1}$ of $\mathrm{P}_{2} \mathrm{O}_{5}$, $60 \mathrm{~kg} \mathrm{ha}^{-1}$ of $\mathrm{K}_{2} \mathrm{O}$ and $1 \mathrm{~kg} \mathrm{ha}^{-1}$ of $\mathrm{B}$, which were provided by the sources of urea, simple superphosphate, potassium chloride and borax, respectively.

Sprinkler irrigation was used daily to keep the soil continuously moist and adequate for better crop development.

The harvests were carried out when pods were at the $\mathrm{R}_{6}$ reproductive stage, using the reference scale of Fehr \& Caviness (1977), adapted by Costa \& Marchezan (1982). The plants were cut just above the soil surface and taken to the laboratory where the pods were removed.

We evaluated the number of pods/ plant; number of seeds/pod; fresh weight of pods/plant; fresh weight of 100 seeds; estimated total productivity of immature seeds (obtained from the number of plants $/ \mathrm{m}^{2}$, number of pods/plant, mean number of seeds/pod and mean mass of 100 seeds). Moisture content was determined by the gravimetric method, protein was quantified by the micro Kjeldahl method, according to AOCS (1988), and lipids were determined by Soxhlet extraction according to the method of AOCS (1988). Ash content was determined according to the method proposed by the AOCS (1988), through complete incineration of the sample in a muffle oven, with an initial temperature of $150^{\circ} \mathrm{C}$, an increasing of 50 to $50^{\circ} \mathrm{C}$ every 30 minutes, until reaching the final temperature of $550^{\circ} \mathrm{C}$. Carbohydrates were determined by the difference as proposed by the AOCS (1988). Isoflavones were quantified by high performance liquid chromatography (HPLC) following the method of Berhow (2002). Kunitz trypsin inhibitor (KSTI) was determined in extracts obtained from defatted flour, by using a standard trypsin with BPNA as substrate and reading absorbance at $\lambda=410 \mathrm{~nm}$, according to Kakade et al. (1974) changed per Hamerstrand et al. (1981).

The data were submitted to analysis of variance by the F test, according to the proposed design, and the means were compared by Tukey's test at the $5 \%$ probability level, using the Estat program (System for Statistical Analysis), version 2.0.

\section{RESULTS AND DISCUSSION}

Significant differences were found at the $5 \%$ probability level among treatments for all agronomic characteristics examined, except for number of seeds per pod (Table 1).

Regarding the number of pods per plant, the genotypes were not different: JLM004 presented 48.56 pods, while JLM003 presented 48.94 and JLM010 51 pods. The highest value for this characteristic was observed in genotypes JLM024 $(70,62)$ and JLM030 $(75,10)$, not differing from both. In general, vegetable soybean genotypes with smaller numbers of pods have seeds that are relatively large. All the evaluated genotypes can be utilized commercially, because according to Nguyen (2001), even commercial soybean cultivars consumed as vegetal (green) should produce on average 50 to 70 pods per plant.

Charlo et al. (2008), studying performance of two vegetable soybean genotypes (CNPSOI and JLM010), according to different spacings between plants $(0.05 \mathrm{~m}, 0.10 \mathrm{~m}$ and $0.15 \mathrm{~m})$, sowed in Jaboticabal, showed that the genotype CNPSOI planted with a spacing of $0.15 \mathrm{~m}$ had the highest mean number of pods per plant (65.25), that is, a value similar to that found in the present work. However, these values 
Table 1. Mean values of five agronomic characteristics in five genotypes of vegetable soybean (valores médios de cinco características agronômicas em cinco genótipos de soja-hortaliça). Jaboticabal, UNESP-FCAV, 2009.

\begin{tabular}{lccccc}
\hline Genotype & $\begin{array}{c}\text { Number of } \\
\text { pods per plant }\end{array}$ & $\begin{array}{c}\text { Number of seeds } \\
\text { per pod }\end{array}$ & $\begin{array}{c}\text { Weight of pods } \\
\text { per plant (g) }\end{array}$ & $\begin{array}{c}\text { Fresh weight of } \\
\mathbf{1 0 0 ~ s e e d s ~ ( g ) ~}\end{array}$ & $\begin{array}{c}\text { Estimated total } \\
\text { yield (kg ha }\end{array}$ \\
\hline JLM003 & $48.94 \mathrm{~b}$ & $2.12 \mathrm{a}$ & $79.43 \mathrm{~b}$ & $48.67 \mathrm{~b}$ & $5,721.50 \mathrm{~b}$ \\
JLM004 & $48.56 \mathrm{~b}$ & $2.29 \mathrm{a}$ & $78.44 \mathrm{~b}$ & $50.00 \mathrm{~b}$ & $6,177.05 \mathrm{~b}$ \\
JLM010 & $51.00 \mathrm{~b}$ & $2.12 \mathrm{a}$ & $136.04 \mathrm{a}$ & $92.52 \mathrm{a}$ & $11,121.22 \mathrm{a}$ \\
JLM024 & $70.62 \mathrm{a}$ & $2.31 \mathrm{a}$ & $120.47 \mathrm{a}$ & $46.43 \mathrm{~b}$ & $7,481.00 \mathrm{ab}$ \\
JLM030 & $75.10 \mathrm{a}$ & $2.08 \mathrm{a}$ & $119.52 \mathrm{a}$ & $57.49 \mathrm{~b}$ & $10,012.55 \mathrm{ab}$ \\
\hline F Test & $14.65^{* *}$ & $1.19^{\mathrm{NS}}$ & $11.96^{* *}$ & $42.38^{* *}$ & $5.85^{* *}$ \\
DMS (Tukey, 5\%) & 15.23 & 0.43 & 34.23 & 13.28 & $4,425.85$ \\
\hline CV (\%) & 11.48 & 8.89 & 14.22 & 9.98 & 24.22 \\
\hline
\end{tabular}

Means followed by the same letter in the column do not differ according to Tukey's test at the 5\% probability level (médias seguidas da mesma letra na coluna não diferem entre si pelo teste de Tukey ao nível de $5 \%$ de probabilidade); ${ }^{*}$, NS significant at the $1 \%$ probability level and not significant at the $5 \%$ probability level by the $\mathrm{F}$ test, respectively $\left(* *\right.$, ${ }^{\text {ss }}$ significativo ao nível de $1 \%$ de probabilidade e não significativo ao nível de 5\% de probabilidade pelo teste F, respectivamente); DMS: Least Significant Difference (diferença minima significativa).

Table 2. Means of chemical centesimal composition, isoflavones and Kunitz Trypsin Inhibitor (KSTI) of five genotypes of vegetable soybean (médias composição química centesimal, isoflavonas e inibidor de tripsina Kunitz de cinco genótipos de soja-hortaliça). Jaboticabal, UNESP-FCAV, 2009.

\begin{tabular}{|c|c|c|c|c|c|c|c|}
\hline Genotype & $\begin{array}{c}\text { Moisture } \\
(\%)^{1}\end{array}$ & $\begin{array}{l}\text { Proteins } \\
\text { (\%) }\end{array}$ & $\begin{array}{l}\text { Lipids } \\
\text { (\%) }\end{array}$ & $\begin{array}{l}\text { Ash } \\
(\%)\end{array}$ & $\begin{array}{c}\text { Carbohydrates } \\
(\%)\end{array}$ & 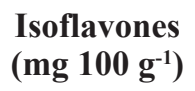 & $\begin{array}{c}\text { KSTI } \\
\left(\mathrm{mg} \mathrm{100g}^{-1}\right)\end{array}$ \\
\hline JLM003 & $65.59 \mathrm{a}^{2}$ & $14.72 \mathrm{~b}$ & $4.70 \mathrm{a}$ & $1.74 \mathrm{a}$ & $13.24 \mathrm{~b}$ & $26.90 \mathrm{bc}$ & $15.40 \mathrm{~b}$ \\
\hline JLM004 & $66.13 \mathrm{a}$ & $14.71 \mathrm{~b}$ & $3.95 \mathrm{ab}$ & $1.53 \mathrm{a}$ & $13.68 \mathrm{~b}$ & $22.67 \mathrm{c}$ & $14.66 \mathrm{~b}$ \\
\hline JLM010 & $60.57 \mathrm{~b}$ & $16.54 \mathrm{a}$ & $3.93 \mathrm{ab}$ & $1.90 \mathrm{a}$ & $17.06 \mathrm{a}$ & $69.54 \mathrm{a}$ & $15.71 \mathrm{~b}$ \\
\hline JLM024 & $60.25 \mathrm{~b}$ & $16.33 \mathrm{a}$ & $3.51 \mathrm{~b}$ & $1.71 \mathrm{a}$ & $18.20 \mathrm{a}$ & $92.62 \mathrm{a}$ & $17.80 \mathrm{a}$ \\
\hline JLM030 & $61.68 \mathrm{ab}$ & $14.67 \mathrm{~b}$ & $3.51 \mathrm{~b}$ & $1.53 \mathrm{a}$ & $18.60 \mathrm{a}$ & $46.13 \mathrm{~b}$ & $13.90 \mathrm{~b}$ \\
\hline F Test & $7.84^{* *}$ & $8.39^{* *}$ & $3.82^{*}$ & $1.16^{\mathrm{NS}}$ & $16.28^{* *}$ & $32.75^{* *}$ & $12.38^{* *}$ \\
\hline DMS (Tukey, 5\%) & 4.52 & 1.48 & 1.12 & 0.63 & 2.82 & 23.24 & 1.88 \\
\hline CV (\%) & 3.19 & 4.27 & 12.67 & 16.75 & 7.76 & 19.99 & 5.39 \\
\hline
\end{tabular}

${ }^{1}$ Calculated based on fresh weight ( ${ }^{1}$ cálculo baseado na matéria fresca); ${ }^{2}$ Means followed by the same letter in the column do not differ according to Tukey's test at the 5\% probability level ( ${ }^{2}$ médias seguidas da mesma letra na coluna não diferem entre si pelo teste de Tukey ao nível de $5 \%$ de probabilidade); ${ }^{*},{ }^{*},{ }^{\text {NS }}$ significant at the $5 \%$ probability level, significant at the $1 \%$ probability level, and not significant at $5 \%$ probability level by the $\mathrm{F}$ test, respectively $\left(* * *,{ }^{*}\right.$ significativo ao nível de $5 \%$ de probabilidade, significativo ao nível de $1 \%$ de probabilidade e não significativo ao nível de $5 \%$ de probabilidade pelo teste F, respectivamente); DMS: Least Significant Difference (diferença minima significativa).

are greater than those found in the work of Castoldi et al. (2009), where four soybean vegetable genotypes (JLM003, JLM010, JLM018 and CNPSOI) spaced $0.10 \mathrm{~m}$ between plants were evaluated in Jaboticabal using two planting periods (December 18, 2004 and September $18,2005)$. These authors observed that the number of pods per plant varied from 31.42 to 59.06, with the genotype CNPSOI (48.00) not differing from the genotype JLM003 (42.78). This difference in values can be explained by the different spacing between plants, as increased population density (smaller spacing between plants), results in increased competition for light, water and nutrients, causing consequently a lower number of pods per plant.

Regarding number of seeds per pod, no significant differences were observed among the genotypes, and it varied from 2.08 (JLM030) to 2.31 (JLM024). Soybean genotypes to be consumed as a vegetable must have large seeds, therefore this characteristic of less seed per pod can be compensate by seed size.

Castoldi et al. (2009) demonstrated that for the number of seeds per pod, a statistical difference was observed among genotypes. JLM018 presented the lowest mean (1.8) while JLM003 genotype presented 2.2 seeds per pod. Although there is statistical difference, the values found in the experiment of Castoldi et al. (2009) are close to the values found in the current experiment. This closeness in the values for the number of seeds per pod of the experiments in question may have occurred by the similarity in the agroclimatic conditions of cultivation, since both experiments were deployed in the same place and similar times.

Similar trend was noted in other study of Castoldi et al. (2008), in wich despite significant difference among genotypes, the number of seeds per pod 
were respectively $1.86,2.06,2.16,2.20$, $2.37,2.45$ and 2.63 for the genotypes JLM018, JLM010, CNPSOI, JLM024, JLM003, JLM019 and BRS216, and were similar to those found in the current experiment $(2.08,2.12,2.12,2.29$ and 2.31, respectively for genotypes JLM030, JLM003, JLM010, JLM004 and JLM024). An exception was observed on the commercial genotype BRS 216, which has small seed size and consequently greater number of seeds per pod.

The weight of pods per plant was greater for the genotype JLM010 (136.04 g), which did not differ statistically from genotypes JLM024 (120.47 g) and JLM030 (119.52 g). The lowest value for this characteristic was observed in the genotype JLM004 (78.44 g).

Castoldi et al. (2009) found mean values for weight of pods per plant from $84.60 \mathrm{~g}$ (JLM003) to 66.70 (JLM018), which are closer to the lower amounts found in the present study. This can be explained by the difference in spacing between plants; that is, while we used a spacing of $0.15 \mathrm{~m}$ between plants, in the study of Castoldi et al. (2009) the spacing between plants utilized was $0.10 \mathrm{~m}$.

Such explanation is in line with one of the results reported by Castoldi et al. (2006) that when the genotypes are planted with a spacing of $0.15 \mathrm{~m}$, the weight of the pods per plant increases significantly compared to that with spacings of $0.05 \mathrm{~m}$ and $0.10 \mathrm{~m}$.

One reason for the increase in the weight of pods of plants cultivated in larger spaces may be due to a greater light interception, in plants more spaced, between stages $\mathrm{R}^{1}$ (beginning the flowering) and $\mathrm{R}^{5}$ (beginning the grain filling), which permits greater movement of nutrients into the pods and consequently greater share of these.

For fresh weight $(\mathrm{g})$ of 100 seeds we observed $92.52 \mathrm{~g}$ for the genotype JLM010, indicating that this genotype has large seeds. According to CarrãoPanizzi (2006), large seeds facilitate cooking and eating soybeans as a vegetable because the larger the volume the easier it is to shuck the seeds. Therefore, it is important to select genotypes with greater fresh weight of
100 seeds.

Charlo et al. (2008) also found that the genotype JLM010 has large seeds $(85.25 \mathrm{~g})$ in relation to other genotypes, which is very desirable in vegetable soybean cultivars. These findings are similar to those reported by Castoldi et al. (2006) who showed that for the December planting, the largest mean fresh weights of 100 seeds were observed in the genotypes JLM010 (68.19 g) and JLM003 (62.20 g). For the September planting, the genotype JLM010 was the one that showed the best performance $(86.97 \mathrm{~g})$ of all the genotypes.

The values above are similar to those found by Castoldi et al. (2009), who showed that the largest mean fresh weights of 100 seeds were observed in the genotype JLM010 (68.2 g) sown in September, and that corroborates with the study of Smiderle et al. (2007) in assessments of productivity and quality of seeds of eight vegetable soybean genotypes in the Roraima's cerrado, where the greatest fresh weight $(\mathrm{g})$ of 100 seeds occurred for the genotype JLM 10 (93 g).

The genotype JLM010 showed a higher value of estimated total productivity of immature seeds (11.12 t/ha), not differing statistically from the genotypes JLM030 (10.01 t/ha) and JLM024 (7.48 t/ha).

As in the present study, Costa et al. (2005), evaluating 10 varieties of vegetable soybean in Montes Claros, found that the genotype JLM003, showed the lowest productivity (Table 1).

In the experiment of Smiderle et al. (2007), the yields were significantly lower (3.45 t/ha to $5.33 \mathrm{t} / \mathrm{ha}$, respectively for genotypes JLM 18 and JLM 08), because following the productivity calculation, these authors separated pods with 0 seed, 1 seed, 2 seeds and 3 seeds. This demonstrates the importance of separating the pods, so that the calculation of productivity is not overestimated, since for vegetable soybean are recommended only pods with two or more seeds.

Means for the chemical proximate composition, levels of isoflavones and Kunitz trypsin inhibitor evaluated for five genotypes of vegetable soybean are presented in Table 2.

The genotypes with the lowest and highest moisture were respectively JLM024 (60.25\%) and JLM004 (66.13\%).

Crancianinov et al. (2005) determined the chemical composition of the vegetable soybean line BRM9452273 , in $\mathrm{R}_{6}$ reproductive stage, and found that the moisture content was $67 \%$; this $\mathrm{R}_{6}$ moisture level is similar to that reported here. It was also reported that the consumption of green soybean at stage $\mathrm{R}_{6}$ is healthy, because it constitutes a vegetable with high nutritive value, besides having an elevated moisture content which confers good texture to the seeds.

Similar results were found in the study conducted by Bates et al. (1977) who evaluated the protein quality of mature green soybean, mature dry soybean and sprouting soybean at the University of Florida, where they found that the moisture level for the mature green soybean was $69.4 \%$.

All these values are in agreement with those found by USDA (2008) which reports that the quantity of water present in green soybean, boiled with salt and drained is $68.60 \mathrm{~g} / 100 \mathrm{~g}$ $(67.50 \%)$.

In relation to protein content, the genotype JLM010 (16.54\%) showed the highest value, differing statistically from the others except for JLM024 (16.33\%) (Table 2).

Protein contents in the current experiment are lower than that one found by Castro et al. (1973) (29.2 to $57.9 \%$ ), Pereira \& Oliveira (2004) (30 to $45 \%$ ) and Kamizake et al. (2006) (42.2 to $45.4 \%$ ). Differences detected by these authors are due to analyzes of the chemical composition of matured grain soybean cultivars, which have a maximum of $12 \%$ moisture, in contrast to vegetable soybean, which has more than $60 \%$ moisture. This affirmation is in accordance with Masuda (1991), who reported that the chemical compounds vary with the stages of growth of the plant, therefore the observed differences between grain and vegetable soybean.

Crancianinov et al. (2005) reported that the protein level in vegetable 
soybean was $12 \%$, value close to that obtained in the current experiment, which means that it would require the ingestion of $210 \mathrm{~g}$ of vegetable soybean, according to FDA (1991) for a healthy $\operatorname{diet}(25 \mathrm{~g}$ of soybean protein).

The protein composition of vegetable soybean cultivars studied here is also in accordance to values found by Masuda (1991) (11.40\%) and by the USDA (2008) (12.95\%), where this product stands out as an excellent source of proteins.

The genotype JLM003 showed the highest lipid content (4.70\%), which did not differ statistically from the genotypes JLM004 (3.95\%) and JLM010 (3.93\%). The lowest concentrations were determined for the genotypes JLM024 and JLM030 (both $3.51 \%$ ) (Table 2).

According to Moraes et al. (2006), as the level of protein increases, the level of oils decreases, which was noted also in the present study. Therefore, we can state that for vegetable soybean, the ideal would be seeds with high concentration of protein and consequently low concentration of oils, thereby making this a vegetable not only having substantial flavor and being rich in protein but also being low in calories.

Crancianinov et al. (2005) reported that lipid concentration increases from stage $\mathrm{R}_{6}(5 \%)$ to stage $\mathrm{R}_{8}(17 \%)$. The grain type soybean thereby has a higher oil content compared to the vegetable type soybean, which makes the former more caloric, when considering the dry mass.

The USDA (2008) reports that the amount of lipids present in green soybean is $6.80 \mathrm{~g} / 100 \mathrm{~g}(6.80 \%)$, demonstrating the low caloric character of the genotypes in question. Average lipid level in this experiment was $3.92 \%$, a value lower than the obtained by the USDA (2008). This may have occurred due to different temperatures during the filling stage of pods, since according to Sediyama et al. (1985), the oil and protein contents, of soybean grain are influenced by temperature.

Data presented in Table 2 indicate that there was no significant difference among the genotypes evaluated for ash content, which showed values of
$1.53 \%$ (JLM004 and JLM030) to $1.90 \%$ (JLM010). A similar data of $1.70 \%$ was reported by the USDA (2008).

Comparing the percentage of ash present in grain and vegetable soybean, studies of Ciabotti et al. (2006) and Kamizake et al. (2006) reported that the grain soybean presents higher quantities of ash (between $4.51 \%$ to $5.24 \%$ and $3.64 \%$ to 3.84 , respectively). This is due to the fact that since the beginning of the reproductive stage of grain soybean to seed maturity, the plant will have available a longer period of time for the accumulation of chemical components.

Carbohydrate level was not statistically different among the genotypes. The observed values were $18.60 \%$ for JLM030, $18.20 \%$ for JLM024 and $17.06 \%$ for JLM010. These values are higher than those found by USDA (2008) (11.05 g/100g) where the quantity of dietary fiber $(4.20 \mathrm{~g} / 100 \mathrm{~g})$ was reported separate from the quantity of carbohydrates, which was not done in the present results.

With respect to isoflavones, the genotype JLM024 had a high content (92.62 mg $100 \mathrm{~g}^{-1}$ of sample), not differing statistically from the genotype JLM010 (69.54 mg $\left.100 \mathrm{~g}^{-1}\right)$. Crancianinov et al. (2005) found higher isoflavone concentrations in the stages $R_{6}(42.63 \mathrm{mg} / 100 \mathrm{~g})$ and $\mathrm{R}_{7}(49.20 \mathrm{mg} / 100 \mathrm{~g})$. Despite that the cultivar studied by Crancianinov et al. (2005) showed a high quantity of total isoflavones in stage $R_{7}$, but this value was lower than the highest value observed in the present study (92.62 $\mathrm{mg} / 100 \mathrm{~g}$ of sample) and higher than the lowest observed value $\left(22.67 \mathrm{mg} 100 \mathrm{~g}^{-1}\right.$ of sample). This can be explained by the environmental and genetic differences that affect concentrations of isoflavones in soybean seeds (Tsukamoto et al., 1995; Carrão-Panizzi et al., 1999).

Simone et al. (2000) studied the retention and changes of soybean isoflavones and carotenoids in immature soybean seeds (Edamame) during processing; they observed that the level of total isoflavones varied from 70.2 $\mathrm{mg} / 100 \mathrm{~g}$ to $230.8 \mathrm{mg} / 100 \mathrm{~g}$, which were higher than those found in the present experiments. It was because they were calculated based on dry weight and not on fresh weight as in the study in question.

In relation to the amount of Kunitz trypsin inhibitor (KSTI), the genotype JLM024 showed the highest mean (17.80 mg/100 $\mathrm{g}$ of sample), differing from the other genotypes which showed mean values of $13.9 \mathrm{mg} / 100$ $\mathrm{g}$ to $15.71 \mathrm{mg} / 100 \mathrm{~g}$ sample. Kumar et al. (2006) evaluated the physicochemical properties of immature pods of Japanese soybean cultivars and found that the amount of Kunitz trypsin inhibitor varied from $5.6 \mathrm{mg} / \mathrm{g}$ (Enrei) to $25.5 \mathrm{mg} / \mathrm{g}$ (Hatsataka), demonstrating different values for each genotype.

According to Morais \& Silva (1996) this anti-nutritional factor is actually not a problem, because soybeans, for human consumption, are always cooked. The absence of this factor in the plant, however, results in less cost in processing and greater safety in the direct utilization of soybean seeds.

According to the results of the agronomic, functional and antinutritional characteristics evaluated in this study, we suggest the genotype JLM010 as the most recommended for the region of Jaboticabal. This genotype also showed better agronomic characteristics for production of vegetable soybean and also displayed better functional properties.

\section{ACKNOWLEDGEMENTS}

Fundação de Amparo à Pesquisa do Estado de São Paulo (FAPESP) is thanked for awarding a master's studentship (Process no 05/58238-6) and Research Assistance Grant (Process no 05/58714-2).

\section{REFERENCES}

AOCS - American Oil Chemists Society. 1988. Official methods and recommended practices of the American Oil Chemists' Society. 3. Edition. Champaign. Vol. 1-2.

BATES RP; KNAPP FW; ARAUJO PE. 1977. Protein quality of green-mature, dry mature and sprouted soybeans. Journal of Food Science 42: 271-272.

BERHOW MA. 2002. Modern analytical techniques for flavonoid determination. In: BUSLIG BS; MANTHEY JA (eds). Flavonoids in the living cell. New York: Klusher Academic. p. 61-76. (Adv. Exp. Méd. 
Biol., v. 505).

BRASIL. MINISTÉRIO DA AGRICULTURA. 2007, 12 de janeiro. Produção e exportação anual de soja. Disponível em http://www. dtr2004.saude.gov.br/nutricao/acoes_anemia. php.

CARRÃO-PANIZZI MC; BELÉIA ADP; KITAMURA K; OLIVEIRA MCN. 1999. Effects of genetics and environment on isoflavone content of soybean from different regions of Brazil. Pesquisa Agropecuária Brasileira 34: 1787-1795.

CARRÃO-PANIZZI MC. 2006. Edamame ou soja-hortaliça: fácil de consumir e muito saudável. Informe Agropecuário 27: 59-64.

CASTOLDI R; BRAZ LT; CHARLO HCO; VARGAS PF; CARRÃO-PANIZZI MC; MENDONÇA JL. 2006. Influência do espaçamento entre plantas em características agronômicas de dois genótipos de ciclo tardio de soja-hortaliça, em JaboticabalSP. In: CONGRESSO BRASILEIRO DE OLERICULTURA, 46. Resumos... Goiânia: Associação Brasileira de Horticultura (CDRom).

CASTOLDI R; CHARLO HCO; BRAZ LT; MENDONÇA JL; CARRÃO-PANIZZI MC; ITO LA. 2008. Desempenho de genótipos de soja-hortaliça, em Jaboticabal-SP. Acta Horticulturae 769: 125-128.

CASTOLDI R; CHARLO HCO; VARGAS PF; BRAZ LT; MENDONÇA JL; CARRÃOPANIZZI MC. 2009. Desempenho de quatro genótipos de soja-hortaliça, em dois anos agrícolas. Horticultura Brasileira 27: 256-259.

CASTRO ATB; MILLAN A; LAGO RCA. 1973. Contribuição ao estudo da soja no Brasil. Rio de Janeiro: Centro de Tecnologia Agrícola e Alimentar do Ministério da Agricultura. 28 p. (Boletim técnico, 10).

CHARLO HCO; CASTOLDI R; VARGAS PF; BRAZ LT; MENDONÇA JL. 2008. Desempenho de genótipos de soja-hortaliça de ciclo precoce [Glycine max (L.) Merril] em diferentes densidades. Ciência e Agrotecnologia 32: 630-634.

CHIBA Y. 1991. Postharvest processing, marketing and quality degradation of vegetable soybean in Japan. In: WORKSHOP [ON] VEGETABLE SOYBEAN. Proceedings... Taiwan: Council of Agriculture. p. 109-112.

CIABOTTI S; BARCELLOS MFP; MANDARINO JMG; TARONE AG. 2006. Avaliações químicas e bioquímicas dos grãos, extratos e tofus de soja comum e de soja livre de lipoxigenase. Ciência e Agrotecnologia 30: 920-929.

COSTA JA; MARCHEZAN E. 1982.
Características dos estádios de desenvolvimento da soja. Campinas: Fundação Cargill. 30 p.

COSTA CA; MENDONÇA JL; FERNANDES KO. 2005. Avaliação de genótipos de soja para consumo como hortaliça em Montes ClarosMG. In: CONGRESSO BRASILEIRO DE OLERICULTURA, 45. Resumos... Fortaleza: Associação Brasileira de Horticultura (CDRom).

CRANCIANINOV WS; FREITAS AM; SANTANA AC; MANDARINO JMG; CARRÃO-PANIZZI MC. 2005. Composição química de soja verde para consumo como hortaliça. In: SIMPÓSIO LATINO AMERICANO DE CIÊNCIA DE ALIMENTOS, 6. Resumos... Campinas: Unicamp/FEA: SBCTA.

EMBRAPA (Empresa Brasileira de Pesquisa Agropecuária). 1999. Centro Nacional de Pesquisa de Solos. Sistema brasileiro de classificação de solos: produção de informação. Rio de Janeiro. 412 p.

EMBRAPA (Empresa Brasileira de Pesquisa Agropecuária). 2003. Tecnologia de produção de soja - região central do Brasil 2004. Londrina. 237 p. (Sistemas de Produção, 4).

FDA (Food and Drug Administration). 1991. Department of Health and Human Services. Food labeling: general requirements for health claims for food. Fed Regist. 56: 60537-60566.

FEHR WR; CAVINESS CE. 1977. Stages of soybean development. Ames: (Special Report 80). Cooperative Extension Service. $11 \mathrm{p}$.

HAMERSTRAND GE; BLACK LT; GLOVER JD. 1981. Trypsin inhibitors in soy products: modification of the standard analytical procedure. Cereal Chemistry 51: 42-45.

KAKADE ML; RACKIS JJ; McGHEE JE; PUSKI G. 1974. Determination of trypsin inhibitor analysis of an improved procedure. Cereal Chemistry 51: 376-382.

KAMIKAZE NKK; NOVACKI C; ZAIA DAM. 2006. Determinação de proteínas e lipídeos totais, umidade, cinzas, macro $(\mathrm{Ca}, \mathrm{Mg}$, $\mathrm{K})$ e micro elementos ( $\mathrm{Fe}, \mathrm{Cu}, \mathrm{Mn}, \mathrm{Zn}$ ) em cultivares de soja [Glycine $\max ($ L.) Merrill] não-transgênicas e transgênicas. Semina: Ciências Exatas e Tecnológicas 27: 175-181.

KUMAR V; RANI A; BILLORE SD; CHAUHAN GS. 2006. Physico-chemical properties of immature pods of Japanese soybean cultivars. International Journal of Food Properties 9: 51-59.

MASUDA R. 1991. Quality requirement and improvement of vegetable soybean. In: WORKSHOP [ON] VEGETABLE SOYBEAN. Proceedings... Taiwan: Council of Agriculture. p. 92-102.

MORAES RM; JOSÉ IC; RAMOS FG; BARROS EG; MOREIRA MA. 2006. Caracterização bioquímica de linhagens de soja com alto teor de proteína. Pesquisa Agropecuária Brasileira 41: 725-729.

MORAIS AAC; SILVA AL. 1996. Soja: suas aplicações. Rio de Janeiro: Médici Editora Médica e Científica. 259 p.

NGUYEN VQ. 2001. Edamame (vegetable green soybean). In: RURAL INDUSTRIES RESEARCH \& DEVELOPMENT. The new rural industries: a handbook for farmers and investors. Austrália. p. 49-56.

PEREIRA CASP; OLIVEIRA FB. 2004. Soja, alimento e saúde: valor nutricional e preparo. Viçosa: UFV. 102 p.

RAIJ BV; CANTARELLA H; QUAGGIO JA; FURLANI AMC. 1997. Recomendações da adubação e calagem para o Estado de São Paulo. $2^{\mathrm{a}}$ Edição. Campinas: IAC. 285 p. (Boletim Técnico, 100).

SEDIYAMA T; PEREIRA MG; SEDIYAMA CS; GOMES JLL. 1985. Cultura da soja: parte I. Viçosa: UFV, 96 p.

SHANMUGASUNDARAM S; YAN MR. 2004. Global expansion of high value vegetable soybean. In: WORLD SOYBEAN RESEARCH CONFERENCE, 7.; INTERNATIONAL SOYBEAN PROCESSING AND UTILIZATION CONFERENCE, 4.; BRAZILIAN SOYBEAN CONGRESS, 3. Proceedings... Foz do Iguaçu: Embrapa Soja. p. 915-920.

SIMONE AH; SMITH M; WEAVER DB; VAIL T; BARNES S; WEI CI. 2000. Retention and changes of soy isoflavones and carotenoids in immature soybean (Edamame) during processing. Journal of Agriculture and Food Chemistry 48: 6061-6069.

SMIDERLE OJ; GIANLUPPI V; SILVA SRG; SILVA JB. 2007. Produtividade e qualidade de sementes de genótipos de soja-hortaliça em cerrado de Roraima 2006/2007. In: REUNIÃO DE PESQUISA DE SOJA DA REGIÃO CENTRAL DO BRASIL, 24. Resumos... Londrina: Embrapa Soja. p. 159-161.

TSUKAMOTO C; SHIMADA S; IGITA K; KUDOU S; KOKUBUN M; OKUBO K; KITAMURA K. 1995. Factors affecting isoflavones content in soybean seeds: changes in isoflavones, saponins and composition of fatty acids at different temperatures during seed development. Journal of Agriculture and Food Chemistry 43: 1184-1192.

USDA-United States Departament of Agriculture. 2008, 08 de fevereiro. Disponível em http:// www.nal.usda.gov/fnic/foodcomp/cgi-bin/ list_nut_edit.pl. 